Detection of Escherichia Coli and Proteus Mirabilis Extended -Spectrum

$\beta$-Lactamase Isolated from Urinary Tract Infections

Fatima Amer ABD Jabar, Lamiaa Saoud Abbod and Duaa Adnan Kadhum Alutbi

\title{
Detection of Escherichia coli and Proteus Mirabilis Extended -Spectrum $\beta$-Lactamase Isolated from Urinary Tract Infections
}

\author{
Fatima Amer ABD Jabar' ${ }^{1}$, Lamiaa Saoud Abbod ${ }^{2}$ and Duaa Adnan Kadhum Alutbi ${ }^{3}$ \\ 1, 2,3 Baquba Technical Institute \\ 1 fatimamyar11@gmail.com \\ 2lamiaaabbod@yahoo.com \\ 3.
}

Received 12 September 2015

Accepted 18 October 2016

\section{$\underline{\text { Abstract }}$}

A total of 40 urine specimens were collected from patients admitted to Baaquba Teaching Hospital in Baaquba city for the period from 1/ $12 / 2014$ to $1 / 01 / 2015$. From them 16 isolates belonging to members of the family Enterobacteriaceae (40\%). isolates were identified as E.coli 10 (25\%) and three isolates were identified as proteus mirabilis 6 (15\%). The results showed that only 4 isolates (25\%) were detected as ESBL-producers by using disk approximation method P.mirabilis and E. coli were the species that gave positive results by using this method.

Keywords: Enterobacteriacea, urinary tract infections, Extended Spectrum $\beta$-Lactamases 


\title{
Detection of Escherichia Coli and Proteus Mirabilis Extended -Spectrum $\beta$-Lactamase Isolated from Urinary Tract Infections
}

Fatima Amer ABD Jabar, Lamiaa Saoud Abbod and Duaa Adnan Kadhum Alutbi

\section{الكثف عن انزيمات البيتالاكتاميز واسعة الطيف لبكتريا Escherichia coli و Proteus mirabilis}

\author{
فاطمة عامر عبد الجبار ، لمياء سعود عبود و دعاء عدنان كاظم \\ المعهد التقني بعقوبة
}

ألخلاصة

شملت الدراسة 40عينة جمعت من المرضى المصابين باخماج المجاري البولية من اجناس واعمار مختلفة وتم جمع العينات من مستشفى بعقوبة التعليمي ، للمدة بين 2014/12/1ولغاية/2015/1. أظهرت نتائج الزرع البكتيري على أوساط أكار الماكونكي وأكار الدم ووسط المثيلين الازرق و التتخيص المظهري و الفحوصات الكيموحيوية أن 16 عزلة لئل

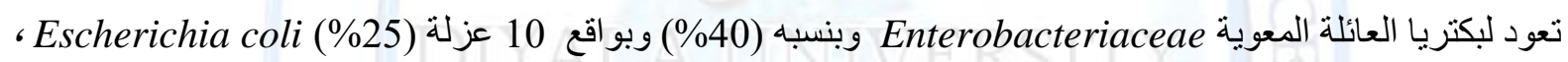

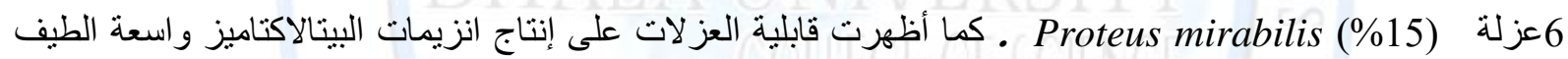
بأستخدام طريقة الاقر اص المتاخمة ( Disc Approximation ) فقد أعطت عزلتين فقط 4 وبنسباء(25\%) نتيجة موجبه لكل من Escherichia colieus mirabilis و .Protis الكلمات المفتاحية: بكتريا العائلة المعوية ،أنزيمات البيتالاكتاميز واسعة الطيف ،التهاب المجاري البولية

\section{Introduction}

Extended-spectrum $\beta$-lactamases (ESBLs) are enzymes that mediate resistance to extendedspectrum (third generation) cephalosporins (e.g. cefotaxime, ceftriaxone, and ceftazidime), monobactam(e.g., azteronam), and to a lesser extent cephamycins(e.g. cefoxitin and cefotetan), but do not affect carbapenems(e.g. imipenem and meropenem) (1) . In recent years, several outbreaks caused by ESBLs production in Enterobacteriaceae have been reported, Various types of ESBLs constitute one of the major mechanisms of resistance of clinical gram-negative bacteria to oxyimino-cephalosporins(such as, cefotaxime and ceftazidime) and to monobactam (2). In general, they are most frequently identified in K.pneumoniae and E.coli; however, many publications have doucomented their growing 


\section{Detection of Escherichia Coli and Proteus Mirabilis Extended -Spectrum $\beta$-Lactamase Isolated from Urinary Tract Infections}

\section{Fatima Amer ABD Jabar, Lamiaa Saoud Abbod and Duaa Adnan Kadhum Alutbi}

incidence in other organisms of the family Enterobacteriaceae, including: Proteus spp., Providencia spp., Citrobacter spp., Enterobacter spp., Serratia marcescens, and others (3).

The emergence of ESBLs has created not only a diagnostic problem but also possess a potential therapeutic challenge for the use of $\beta$-lactams in serious infections caused by the Enterobacteriaceae.

\section{Aims of Study:}

Isolation and identification of some members of the family Enterobacteriaceae from patients with UTI. Detection of production of Extended-spectrum $\beta$-lactamases (ESBLs).

\section{Materials and Methods}

\section{Collection of specimens}

All specimens were collected from patients admitted to Baaquba Teaching Hospital Widemouth containers were used. These were sterilized by hot-air oven at $180 \mathrm{C}^{\circ}$ for 1 hour.

\section{Culture technique}

Clinical specimens were inoculated onto $5 \%$ blood agar and MacConky agar for the isolation of enteric gram-negative rods (4).

\section{Culture characteristics}

For the identification of different enteric gram-negative bacilli, the colonial appearance on simple solid media was studied, after 24 hours incubation at $37 \mathrm{C}^{\circ}$. The Enterobacteriaceae group yielded large, colorless to gray, shining, convex and opaque colonies. Some genera gave characteristic appearance, e.g. swarming growth of Proteus spp. Lactose-fermenting organisms showed pink or reddish colonies when grown on MacConky agar, while the nonlactose fomenters displayed colorless translucent colonies (5).

\section{Biochemical tests}

1. Indole test

2. Urease test 


\section{Detection of Escherichia Coli and Proteus Mirabilis Extended -Spectrum \\ $\beta$-Lactamase Isolated from Urinary Tract Infections}

Fatima Amer ABD Jabar, Lamiaa Saoud Abbod and Duaa Adnan Kadhum Alutbi

\section{Antimicrobial Susceptibility Test}

The most widely used method for susceptibility testing was the disc agar diffusion method. It had the advantage of being simple, economical, and reproducible. The procedure, which was accepted by the National Committee for Clinical Laboratory Standard (NCCLS) was employed, as described by (6).

\section{Preparation of culture medium:}

Muller-Hinton medium was employed. The medium was cooled to (45-50)C and poured into Petridishes on a level surface to a depth of $4 \mathrm{~mm}$. When the medium was hardened, the Petridishes were placed in the incubator at (15-30) minutes to allow excess moisture evaporate.

\section{Preparation of inoculum:}

With a sterile wire loop, the tops of (4-5) isolated colonies of the test organism were picked from the original culture and introduced into a sterile test tube containing $4 \mathrm{ml}$ of nutrient broth. The broth was incubated at $37 \mathrm{C}$ for about (2-6) hours. The growth was adjusted to a MacFarland (No.0.5) turbidity standard using sterile saline or nutrient broth.

\section{Inoculation of plates:}

A sterile cotton wool swab was dipped into suspension, and rotating the swab firmly against the side of the tube above the level of fluid.The swab was streaked in three direction onto the dried surface of a Muller-Hinton plate until the plate was completely and uniformly covered.

\section{Detection of ESBL Production:}

Three methods were performed for detection of ESBLs in isolates that cause bacteremia.All bacterial isolates that were positive to $\beta$-lactamase production were tested for their ability to produce ESBL enzymes. These tests included:

\section{Disk Approximation Method:}

This method was carried out as modified by (7) as follows:

Muller-Hinton agar plate was inoculated with an overnight blood agar culture of the test bacterial isolate as recommended for standard disk diffusion susceptibilities test. Disks containing $30 \mu \mathrm{g}$ cefotaxime, ceftazidime, ceftriaxone, and aztreonam wre placed $15 \mathrm{~mm}$ 


\section{Detection of Escherichia Coli and Proteus Mirabilis Extended -Spectrum \\ $\beta$-Lactamase Isolated from Urinary Tract Infections}

\section{Fatima Amer ABD Jabar, Lamiaa Saoud Abbod and Duaa Adnan Kadhum Alutbi}

(edge to edge) from a disk of augmentin ( $20 \mu \mathrm{g}$ amoxicillin plus10 $\mu \mathrm{g}$ clavulanate) and then incubated for $16-20 \mathrm{hrs}$ at $35^{\circ} \mathrm{C}$. Any enhancement of the zone of inhibition between a $\beta$ lactam disks and augmentin disk gave an indication that the test isolate contains ESBL.

\section{Results and Discussion}

\section{Patients and Specimens}

From a total of 40 specimens which yielded positive growth, there were 16 isolates belonging to members of the family Enterobacteriaceae (40\%). 10 isolates were identified as E.coli $(25 \%)$ and 6 isolates were identified as Proteus (15\%).

Isolation and Identification of Members of the Family Enterobacteriacecae Causing UTI Table (1) illustrate the most common members of the the family Enterobacteriaceae isolated from the patients with UTI.

Table (1): Isolation of Enterobacteriaceae isolated from urine specimens of patients admitted at Baaquba teaching hospital

\begin{tabular}{|c|c|c|}
\hline Bacterial species & Number of cases & $\%$ \\
\hline E.coli & 10 & 25 \\
P.mirabilis & 6 & 15 \\
\hline Total No. of isolates & 16 & 40 \\
\hline
\end{tabular}

Escherichia coli was the most common microorganism isolated from UTI, representing 10 isolates $(25 \%)$. In the present work, it was found that Proteus spp. isolated represented 6 isolates (15\%). An E.coli bacteria were more causes UTI in this study were accounted for (25\%) Table (1), came to approach the percentage obtained by (8) which was (30.4\%), but do not agree with the results obtained by (9) was (65.59\%). The differences in the rates of E.coli isolates is probably due to the level of health Hygienic status in different communities. The intestinal bacteria, especially bacteria E.coli from more types of intestinal family events for urinary tract infections, and this was confirmed by numerous studies (10). In general, E.coli is the causative agent of the vast majority of UTIs, ranging from uncomplicated cystitis to sepsis. Virulence factors present on E.coli enable this organism to infect patients without 


\section{Detection of Escherichia Coli and Proteus Mirabilis Extended -Spectrum $\beta$-Lactamase Isolated from Urinary Tract Infections}

\section{Fatima Amer ABD Jabar, Lamiaa Saoud Abbod and Duaa Adnan Kadhum Alutbi}

genitourinary structural abnormality; whereas, relatively apportunistic organisms that lack virulence factors tend to cause disease in the setting of structural abnormality (11). Proteus mirabilis came in second place by (15\%), came to approach the percentage obtained by(12)which was(18\%), as it was incidence with the findings of the researcher(13) and his group where they found that the incidence of these bacteria was $33.33 \%$, and this is inconsistent with the results referred to by researcher ( 14 ) and his group in a study in Southeast Asia about urinary tract infections because the bacteria isolated Variables sex ratio is $8.3 \%$.chir a lot of studies that the bacterial genus Variables come in second place after the events in bacteria E.coli infections of the urinary tract in all ages and sex (15). The prevalence of Proteus spp. in the present study indicates that urinary infection was mostly environmental rather than fecal in origin, and agrees with what have been reported by (16), i.e. the UTI contracted in the hospital was usually due to Proteus.

\section{Disk Approximation Method:}

This method is also known as double disk synergy test; it was first described by (17). In this test, as discussed previously, any enhancement of the zone of inhibition between a $\beta$-lactam disks and augmentin disk gave an indication that the test strain contains ESBL whose activity is inhibited by clavulanic acid. It was found that only 4 isolates $(25 \%)$ were detected as ESBL-producers by using disk approximation method as shown in Table (3). P.mirabilis and E. coli were the species that gave positive results by using this method.

These results showed that the frequency of ESBL-producing isolates was higher than that reported by other researchers.(18) examined 38 B-lactamase-producing Klebsiella spp. isolates obtained from different clinical samples, and found that only 4 Klebsiella isolates $(10.5 \%)$ were identified as ESBL-producers by using disk approximation method. In another local study by (19), her results revealed that out of 60 B-lactam resistant E. coli and $K$. pneumoniae subsp. pneumoniae isolates, only 11 isolates (18.3\%) were detected as ESBLproducers by using disk approximation method. Disk approximation method has served as the reference method for the detection of ESBL-producing strains for a number of years (20). The detection of ESBL-mediated resistance in Gram-negative bacilli is one of the major problems 


\section{Detection of Escherichia Coli and Proteus Mirabilis Extended -Spectrum $\beta$-Lactamase Isolated from Urinary Tract Infections}

\section{Fatima Amer ABD Jabar, Lamiaa Saoud Abbod and Duaa Adnan Kadhum Alutbi}

in the clinical microbiology laboratories (21). Furthermore, many studies showed that there is a clinical and financial benefit of rapid bacterial identification and early determination of antibacterial susceptibility (22).

Table (3): The Frequency of ESBL-Producing and Non-Producing Isolates by Disk Approximation Method.

\begin{tabular}{|l|c|c|c|}
\hline Bacterial Isolates & No. of Isolates & No. of ESBL-Producers (\%) & $\begin{array}{c}\text { No. of Non ESBL- } \\
\text { Producers (\%) }\end{array}$ \\
\hline E. coli & 10 & $2(20 \%)$ & $8(80 \%)$ \\
\hline p.mirabilis & 6 & $2(33.33 \%)$ & $4(66.67 \%)$ \\
\hline Total & 16 & $4(25 \%)$ & $12(75 \%)$ \\
\hline
\end{tabular}

(23) Reported that from a total of 1699 Enterobacteriaceae isolates, only 336 isolates $(19.8 \%)$ were identified as potential ESBL producers by the double disk synergy test. On the other hand, (24) showed that 35\% of examined Enterobacteriaceae in Thailand were resistant to third generation cephalosporins. In spite of the fact that the disk approximation method is the most widely used test because it is easy to be used and it can be performed in every laboratory. However, this test may lack sensitivity for some reasons such as: the optimum disk placement is not standardized, the inability of clavulanate to inhibit all ESBLs, the loss of clavulanate disk potency during storage, and the inability of the test to detect ESBLs in strains that also able to produce chromosomal cephalosporinases (25). 


\section{Detection of Escherichia Coli and Proteus Mirabilis Extended -Spectrum \\ $\beta$-Lactamase Isolated from Urinary Tract Infections}

Fatima Amer ABD Jabar, Lamiaa Saoud Abbod and Duaa Adnan Kadhum Alutbi

\section{$\underline{\text { References }}$}

1. NCID,1999 :National Center for Infectious Diseases,1999.

2. Gniadkowski, M.(2001). Evolution and epidemiology of extended-spectrum $\beta$-lactamases (ESBLs) and ESBL-producing microorganisms. Clin. Microbiol. Infect.,7:597-608.

3. Rahal, J.J.(2000). Extended-spectrum $\beta$-lactamases: how big is the problem? Clin. Microbiol. Infect.,6(Suppl.2):2-6.

4. Collee, J. G. ; Fraser, A. G. ; Marmion , B. P. and Simmons, A. (1996) . Mackie and McCartney practical medical microbiology . 14thed. Churchill Livingston . pp.173-174.

5. Baron, E.J. and Finegold, S.M. (1994). Microorganisms Encountered In Urinary Tract in Baily \& Scott,s Diagnostic Microbiology. (9th) ed. Mosby Company U.S.A.

6. Bauer, A.W., Kirby, W.M.M., Sherries, J.C., and Turck, M.(1966). Antibiotic susceptibility testing by a standardized single disc method. Am. J. Clin. Path.,45:493-496.

7. Coudron, P.E., Moland, E.S., and Sanders, C.C. 1997. Occurence and detection of extended-spectrum B-lactamases in members of the family Enterobacteriaceae at a Veterans Medical Center: seek and you may find. J. Clin. Microbiol., 35: 2593-2597.

8. Alniaamy, Mohammed khudhair Abaas (2014). Bacteriological study of some genus for bacterial gram-negative resistant to $\beta$-lactam, isolated from urinary tract infections in Diyala province . Master Thesis, College of Education for Pure Science, Diyala University.

9. Khurshid, Thary Ahmed (2005) . A study of some bacterial causes urinary tract infections for patients in Azadi General Hospital in the city of Kirkuk . Master Thesis, Collage of Education, University of Tikrit.

10. Delzell, J.E. and Lefevre, M.L. (2000). Urinary tract infection during pregnancy. Am. Academy of Family Physicians, 35(3):40-66.

11. Al-Autbi, Duaa Adnan Kadhum (2013). Bacteriological study of some species of Enterobacteriaceae isolated from Hospital birth rooms in Baquba city. Master Thesis, College of Education for Pure Science, Diyala University. 


\section{Detection of Escherichia Coli and Proteus Mirabilis Extended -Spectrum $\beta$-Lactamase Isolated from Urinary Tract Infections}

\section{Fatima Amer ABD Jabar, Lamiaa Saoud Abbod and Duaa Adnan Kadhum Alutbi}

12. Allison, C.; Coleman, N.; Jones, P.L.; and Hughes, C. 1992. Ability of Proteus mirabilis to invade human urothelial cells is coupled to motility and swarming differentiation. Infect. Immun. 60: 4740-4746.

13. Khurana, S.; Taneja, N.; Sharma, M. (2002). Extended-spectrum beta-lactamase mediated resistance in urinary tract isolates of family Enterobacteriaceae. Indian J.Med.Res. Oct.116: $145-9$.

14. Ling, J.M.; Lam, A.W.; Chan, E.W.\& Cheng, A.F. (2003). What have we learn from community-aquired infections in Hong Kong? J.Antimicrob.Chemother. Apr.51 (4): 895904.

15. Naas, T., Philippon, L., Poirel, L., Ronco, E., and Nordman, P. 1999. An SHV-derived extended-spectrum B-lactamase in Pseudomonas aeruginosa. Antimicrob. Agents Chemother., 43: 1281-1284.

16. Leigh, D.A., and Wiliams., J.D.(1964). Method for detection of significant bacteriuria in large groups of patients. J. Clin. Path.,17:498-503. 17- Jarlier, V.;

Nicolas, M.; Fournier, G.; and Philippon, A. (1988). Extended broad-spectrum $\beta$ Lactamases conferring transferable resistance to newer $\beta$-lactam agents in Enterobacteriaceae: Hospital prevalence and susceptibility patterns. Rev. Infect. Dis. Vol.10,No. 4 :pp. 867-78.

17. Al-Charakh, A.H. 2005. Bacteriological and genetic study on extended-spectrum Blactamases and bacteriocins of klebsiella isolated from Hilla city. Ph.D. thesis. College of Science. Baghdad University.

18. Hadi, Z.J. 2008. Detection of Extended-Spectrum Beta-lactamases of Ecsherichia coli and Klebsiella spp. isolated from patients with significant bacteriuria in Najaf. M.Sc. Thesis. College of Medicine. Kufa University.

19. Katsanis, G.P., Spargo, J., Ferraro, M.J., Sutton, L., and Jacoby, G.A. 1994. Detection of Klebsiella pneumoniae and Escherichia coli strains producing extended-spectrum Blactamases. J. Clin. Microbiol., 32: 691-696.

20. Arpin, C., Dubois V., Coulange L., Andre' C., Fischer I., Noury P., Grobost F., Brochet j.P., Jullin J., Dutilh B., Larribet G., Lagrange I., and Quentin C. 2003. 


\section{Detection of Escherichia Coli and Proteus Mirabilis Extended -Spectrum $\beta$-Lactamase Isolated from Urinary Tract Infections}

\section{Fatima Amer ABD Jabar, Lamiaa Saoud Abbod and Duaa Adnan Kadhum Alutbi}

Extended-spectrum $\beta$-lactamase-producing Enterobacteriaceae in community and private health care centers. Antimicrob. Agents Chemother., 47(11): 3506-3514.

21. Livermore, D.M., and Brown, D.F.J. 2001. Detection of ß-lactamase-mediated resistance. J. Antimicrob. Chemother., 48: 59-64.

22. Kumar, M.S., Lakshmi, V., and Rajagopalan, R. 2006. Occurrence of extended spectrum beta-lactamases among Enterobacteriaceae species isolated at a tertiary care institute. Ind. J. Med. Microbiol., 24: 208-211.

23. Chanawong, A., M'Zali, F.H., Heritage, J., Lulitanond, A., and Hawkey, P.M. 2001. Discrimination of SHV beta-lactamase genes by restriction site insertion-PCR. Antimicob. Agents Chemother., 45: 2110-2114.

24. Moland, E.S., and Thomson, K.S. 1994. Extended-spectrum B-lactamases of Enterobacteriaceae. J. Antimicrob. Chemother., 33: 666-668. 